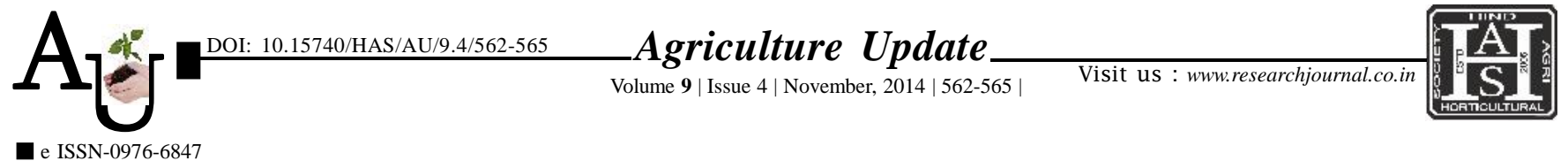

Research Article

\title{
Impact analysis of groundnut FLDs technology on extent of adoption, enhancing the productivity and profitability in Sikar district of Rajasthan
}

\author{
B.L. ASIWAL, AKHTER HUSSAIN, JUNED AKHTER AND LALA RAM
}

Article Chronicle : Received : 23.09.2014;

Revised : 10.10.2014;

Accepted :

23.10.2014

\section{KeY WoRds:}

\section{Front line} demonstration (FLD), Adoption, Productivity, Groundnut
SUMMARY : The impact study was conducted in Sikar district of agro-climatic Zone IIa. To evaluate the productivity potential and profitability of groundnut production technology, the front line demonstrations (FLDs) on groundnut crops were conducted by Bhartia Krishi Vigyan Kendra (BKVK), Fatehpur in Sikar district during three years 2007, 2008 and 2009 were taken for study against farmer's practice. After conduction of demonstrations a significant improvement was found in extent of adoption of seed treatment 43.33 per cent, use of sulphur fertilizer 41.67 per cent, seed rate 35.0 per cent, soil treatment 30.0 per cent, HYVs with 26.67 per cent and plant protection measures 20.00 per cent. The highest yield in FLD (31.33 q ha-1) was recorded in the year 2007; it was 21.20 per cent increase over the farmer's practice $\left(25.85 \mathrm{q} \mathrm{ha}^{-1}\right)$. The 21.20 per cent more yield increases over traditional practices help in improving the additional net income Rs. 8456/- besides incremental benefit cost ratio 2.55 shows direct and positive effect of FLD with increase in extent of adoption of all the improved groundnut production technologies in the study area. Thus, it is concluded that the FLD is an effective technology for changing the knowledge, extent of adoption which ultimate resulting in higher production and productivity of groundnut with additional net profitability of farmers.

How to cite this article : Asiwal, B.L., Hussain, Akhter, Akhter, Juned and Ram, Lala (2014). Impact analysis of groundnut FLDs technology on extent of adoption, enhancing the productivity and profitability in Sikar district of Rajasthan. Agric. Update, 9(4): 562-565.

Author for correspondence :

\section{B.L. ASIWAL}

Bharatia Krishi Vigyan

Kendra, Fatehpur, SIKAR

(RAJASTHAN) INDIA

Email: asiwalbl@

gmail.com

See end of the article for

authors' affiliations 